\title{
RESUME ALIRAN EKONOMI ISLAM KONTEMPORER
}

\author{
Oleh \\ Azizah Nur Adilah \\ 90100118048 \\ Jurusan Ekonomi Islam \\ Fakultas Ekonomi dan Bisnis Islam \\ email: azizahnuradilah00@gmail.com
}

Aliran Ekonomi Islam Kontemporer umumnya diketahui terbagi dalam tiga mazhabr, ketiga mazhab ini memandang ekonomi Islam berdasarkan perspektif mereka masing-masing. Mazhab ekonomi Islam ini antar lain, yaitu aliran Iqtisaduna, aliran mainstream, aliran alternative kritis.

Aliran iqtisaduna diperkasai oleh seorang ulama yang berasal dari Irak bernama Muhammad Baqir Sadr. Dia merupakan seorang ulama syiah yang banyak menyumbangkan pemikirannya terkait ekonomi Islam. Iqtisaduna berarti ekonomi kita. Dalam kitabnya yang berjudul Iqtisadinah tersebut, Baqir Sadr menguraikan ekonomi islam tanpa interfensi pemikir dan sarjana Barat.(Ubay, 2005)

Menurut Sadr, ekonomi Islam merupakan sebuah kombinasi dari tiga elemen dasar, yakni doktrin, konsep-konsep , rasa (emosi batiniah) . ( Sadr, 1981 : 309-310) Baqir Sadr memandandg ekonomi Islam sebagai suatu ksatuan yang univerasal dari syariat Allah, sehingga ekonomi Islam dianggapnya bukanlah sesuatu yang bersifat temporal dan permanen, akan tetapi ekonomi Islam dianggap sebagai suatu doktrin agama yang kebenarannya bersifat mutlak. Ia merupakan rambu-rambu aturan, undang-undang, maupun batasan (hudud) yang berasal dari Allah SWT, yang maha mengetahui perkara yang baik bagi kehidupan manusia. Ekonomi Islam menjadi suatu hal yang tidak bias dipisahkan dari akidah, logika, dan emosi-emosi positif, sehingga dengan demikian ia membawa misi. Baqir Sadr mengatakan bahwa ada tiga prinsip dasar atau kerangka umum sistem Islam: properti multilapisan (multifold property), kebebasan ekonomi yang terbatas, dan keadilan sosial.(Ubay, 2005)

Baqir As Sadr, membedakan ilmu ekonomi dengan doktrin ekonomi dalam menyusun kerangka pikir terkait definisi ekonomi Islam. Dia mencoba membuat 
sebuah interpretasi yang tidak terikat dengan pemikiran-pemikiran yang telah ada, sheingga menghasilkan pemikiran yang benar-benar original (Saleh, 2014).

Sadr berpendapat bahwa sumber daya yang ada adalah tidak terbatas, dan pemikiran mengenai bahwa sumber daya terbatas dengan mutlak ditolak oleh Sadr. Pemikirannya ini dilandasakan dari Qs. Al-Qamar: 49. Selain itu Sadr juga menolak semua pemikiran ekonomi konvensional karena dianggap tidak sesusai dan selaras, sehingga Sadr berusaha menyusun teori-teori baru yang sesuai dengan Al-Qur'an dan Sunnah (Sunarko and Bahari, 2014).

Kedua, mazhab aliran mainstream. Mazhab ini memiliki pendapat yang bertolak belakang dengan mazhab Iqtisaduna. Dimana mazhab ini berpendapat bahwa masalah ekonomi muncul karena sumber daya yang ada terbatas nilainya sedangkan keinginan manusia itu tidak terbatas. Hal ini bertolak belakang dengan pendapat Sadr bahwa sumber daya itu tidaklah terbatas. Mazhab ini berpandangan bahwa di dalam Islam diakui bahwa ada keterbatasan sumber daya yang dapat terjadi, sesuai dengan dalil Qs. Al-Baqarah: 155.

Mazhab mainstream memiliki pandangan dimana mereka memandang permasalahn ekonomi tidak jauh berbeda dengan pandangan ekonomi konvensional. Keterbatasan sumber daya dipandang oleh mazhab ini menjadi sumber permasalahan ekonomi yang terjadi dimasyarakat. Yang membedakan ekonomi Islam dan ekonomi konvensional menurut mazhab ini ialah dari cara penyelesaian masalah ekonomi tersebut. Sehingga dengan cara penyelesaian ini membuat mazhab ini dikenal pula dengan kaidah islamisasi ilmu yang digunakannya (Sunarko and Bahari, 2014).

Ketiga, mazhab alternatif-kritis. Yang menjadi pelopor dari mazhab ini ialah Timur Kuran (Ketua Jurusan Ekonomi University of Sourthen California), Jomo (Yale, Cambridge, Harvad dan Malaysia), Muhammad Arif, dan lain-lain. Mazhab ini mengkritik mazhab sebelumnya. Mazhab ini mengkritik pemikiran dari Baqir As Sadr yang berusaha membuat suatu pemikiran baru yang pada kenyataannya telah ditemukan sebelumnya, kemudian menghilangkan teori lama dan menggantinya menjadi teori baru. Kemudian Mazhab ini juga mengkritisi terkait 
pemikiran aliran mainstream yang seperti meng-copy paste atau hanya menciplak dari ilmu ekonomi neoklasik yang telah ada sebelumnya, dan mengganti variable riba dengan memasukkan zakat serta niat (Sunarko and Bahari, 2014).

Mazhab ini merupakan sebuah mazhab yang kritis. Mereka berpendapat bahawa analisis kritis bukan hanya dilakukan terhadap sosialisme dan kapitalisme, tetapi juga terhadap ekonomi Islam itu sendiri. Mereka yakin bahawa Islam pasti benar, tetapi ekonomi Islam belum tentu benar karena ekonomi Islam merupakan hasil tafsiran manusia atas al-Qur'an dan al-Sunnah sebagai epistemologi ekonomi Islam. Teori-teori maupun pemikiran dari ekonomi Islam belum bersifat final, sehingga harus selalu diuji dan dikritisi kebenarannya (Sunarko and Bahari, 2014).

\section{DAFTAR PUSTAKA}

Saleh, M. (2014) 'Pemikiran Ekonomi Islam Muhammad Baqir Ash Shadr', pp. $67-78$.

Sunarko, B. S. and Bahari, Z. Bin (2014) Konferensi Internasional Pembangunan Islami -I Ekonomi Syariah Terkini.

Ubay (2005) 'Pemikiran Ekonomi Islam Muhammad Baqir Sadr', Hunafa, 2, pp. $225-242$. 